IRA-International Journal of Education \& Multidisciplinary Studies

ISSN 2455-2526; Vol.04, Issue 01 (2016)

Institute of Research Advances

http://research-advances.org/index.php/IJEMS

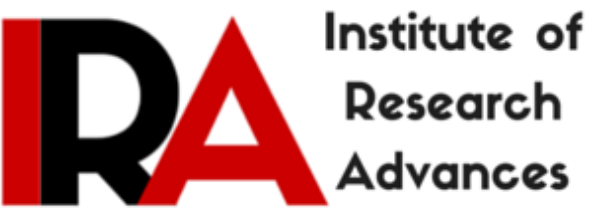

\title{
China against Hollywood: Visible and Invisible Walls
}

\section{Chuanmao Tian}

School of Foreign Studies, Yangtze University, Hubei, 434023 P. R. China.

DOI: http://dx.doi.org/10.21013/jems.v4.n1.p23

\section{How to cite this paper:}

Tian, C. (2016). China against Hollywood: Visible and Invisible Walls. IRA

International Journal of Education and Multidisciplinary Studies (ISSN 2455-2526),

4(1). doi:http://dx.doi.org/10.21013/jems.v4.n1.p23

(C) Institute of Research Advances

\section{(cc) EY-NC}

This works is licensed under a Creative Commons Attribution-Non Commercial 4.0 International License subject to proper citation to the publication source of the work.

Disclaimer: The scholarly papers as reviewed and published by the Institute of Research Advances (IRA) are the views and opinions of their respective authors and are not the views or opinions of the IRA. The IRA disclaims of any harm or loss caused due to the published content to any party. 


\begin{abstract}
Hollywood's global expansion has been met with resistance in many countries. To resist Hollywood, some countries have developed their own way according to their tradition and relationship with the US in politics, economy, culture and diplomacy. Since the People's Republic of China was founded, mainland China's government policy, main-stream ideology, cultural values, economic status and relationship with the US have been ever changing. China is assumed to have adopted various measures to resist Hollywood. The current study suggests that game theory can provide a broad and useful guiding framework in analyzing the relationship, the strategic interactions in particular, between China and Hollywood. This article has discussed the interactions between China and Hollywood at the three stages, namely the planned-economy period (1949-1977), the transitional period of reform and opening-up (1978-1993) and the opening period of China's film market to the West including Hollywood (1994-2009). It is argued that the game between China and Hollywood at each stage is characterized by the corresponding political and economic policies. As a result of this ongoing game, both parties will co-exist through cultural diversities and Hollywood's expansion in China.
\end{abstract}

Keywords: China; Hollywood; film quota; protection month; translator's intervention; criticism

\title{
1. Introduction
}

Hollywood's global expansion has been met with resistance in many countries. To resist Hollywood, some countries have developed their own way according to their tradition and relationship with the US in politics, economy, culture and diplomacy. A case in point is the People's Republic of China. In the planned-economy period (1949-1977) no Hollywood film found its way into mainland China and even after 30 years of reform and opening-up in the country, only a greatly limited number of Hollywood movies can enter China's film market. Therefore, the question to be addressed in this study is what has prevented and restricted the movies from having access to Chinese audiences. The hypothesis is, then, formulated as follows: the government policy is the main reason for Hollywood's difficulty in entering China. In this article game theory will be employed to deal with the interactions between both parties.

\section{Literature review}

In this section we will introduce the relevant studies on the relation between Hollywood and the film industry in other countries including China, expounds the basic idea of game theory as the theoretical basis of this article and finally explores the feasibility of the theory in cultural and media studies.

\subsection{Previous studies}

Piracy might be the first problem Hollywood faces in China. Ting (2007: 1-46) explores film piracy in China, its background and the reason why film piracy flourishes in the country, and then offers some strategies for combating Chinese piracy. However, challenging existing approaches and assumptions, Sigismondi (2009) identifies the phenomenon of Hollywood piracy in China as an agent of American expansion in the region, amplifying the distribution of popular American cultural artifacts.

More researches focus on the relationship between the Chinese film industry and Hollywood. 
Wan and Kraus (2002) examine the relation between Hollywood and Chinese cinema following a political-economic approach. They hold that the Sino-American cinema relationship may be that of friends and foes, and China can find her place in world cinema. Moreover, some researches have explored the strategies against Hollywood. Su (2010) believes that the Chinese government's strategy for using the so-called "main-melody" propagandistic films to battle against Hollywood may be considered partially successful in terms of the technological renovation of cinema operation. Su also revisits the thesis of "cultural imperialism" and calls for a more rational way to explain the complex global-local dialectic. The localization of Hollywood pictures in their globalization process has been discussed. Matusitz (2010) analyzes Disneyland Paris and how glocalization theory has been successfully applied to the adaptation of Disneyland in Paris. This proves that Hollywood in other countries has to adapt itself to local preferences in order to generate maximal profits and remain competitive.

No systematic research has so far been carried out with respect to the relationship between the Chinese film industry and Hollywood during the past six decades. Most researches have been carried out from the perspectives of political theory and cultural theory. Moreover, the relationship between China and Hollywood is not a simple matter of resistance, globalization or localization. However, games inevitably appear between some countries and Hollywood in its global expansion. Therefore, it seems feasible to explore the relation between China's film industry and Hollywood from the perspective of game theory.

\subsection{Game theory}

The object of study in game theory is any interactive situation (Turocy and von Stengel 2002). A game can be briefly defined as having rules and a set of players, such that each player has his/her own set of preferences over a set of action profiles and considers all other players' preferences before making his/her choice of action (Osborne 2003). As Heap and Varoufakis (2004) have summarized, game theory is based on four basic assumptions about the rationality of human behaviors: (i) instrumental rationality, i.e. actors in a game are rational and purposeful decision makers; (ii) common knowledge of rationality, i.e. actors in a game hold expectations about each other, and other actors are likely to inform what is rational for the actor to do; (iii) common priorities, i.e. rational individuals in a game will draw the same inferences on how a game is to be played; (iv) action within the rules of game, i.e. individuals know the rules of the game; in other words, they know all the possible actions and how these actions combine to yield particular payoffs for each player.

These rationality assumptions mean that players in the game are rational and act to maximize the achievement of their "postulated goal[s]" (Brams 2004: xv). The essential elements of a game include the players, the strategies or preferences they choose, the information available to them, the order of play, and the outcome or payoff of the game. A game involves at least two players who make decisions and who can be individuals, communities, corporations, or the government. Each player has his/her own preference and strategy, which is "a complete plan of action that describes what a player will do under all possible circumstances" (Davis 1997: 7). However, not all strategies can be spelled out explicitly because they can be very complicated in the real world. Each player needs to possess information about the situation and other players' strategies or preferences. Moreover, when players choose a strategy to maximize their rewards, they must take into account 
what the others might do. A strategy that is optimal with regard to one set of players is not necessarily optimal for another set. Therefore, when making decisions, players must foresee other players' decisions and know that other players are trying to foresee theirs as well.

2.3 The potentiality of game theory in media studies

As a cultural industry, the film industry has always been an important part of America's globalization strategy. When the culture has been industrialized, its economic function overlaps with its cultural function. The export of cultural products to the rest of the world brings not just a bigger market share and more profits; it also spreads the American lifestyle and values. In the 1930s, the US government realized that using movies, they could influence the sense of history, community, religion and culture and even language in other countries. They could also modify or even rewrite history and traditions. By doing so, they managed to propagandize American values and belief in these regions. Since the WWI, the US has been using various political and economic means to promote its movies in the rest of the world. During the Roosevelt Administration, Hollywood movies became a significant political propaganda tool in enhancing the US image and democracy (Qi 1999: 19-29). Many developing countries including China started to boycott Hollywood as a result.

Therefore, the essence and four major elements of game theory can be applied in studying the relation between China's movie industry and Hollywood. First, both parties are the most important actors in the game of Hollywood's entry into China. Second, as for gaming strategies, they can choose to accept or resist each other. Third, on the balancing elements, judging from Hollywood's situation in China, we can see that since China's reform and opening-up, both parties have chosen the best gaming strategy to maximize the overall gain and reach a win-win end as this is the only way for either of them to receive the best possible result.

Game theory has been widely applied in many academic disciplines, including economics, biology, education, tourism, military strategy, international relations, law, and sociology (Esmaeili et al. 2009; Frey 2010; Law and Pan 2009; Li 2011; Rosas 2010). However, few studies have been made to explore the relationship between different movie cultures with game theory. Chu (2011) attempts to introduce the idea of game theory to the exploration of the cultural conflict, fusion, absorption and resistance between Chinese and Western cultures in the process of globalization from the perspective of game analysis. Wu (2013) analyzes the effectiveness of the balancing strategies from the perspective of game theory, holding that some policies introduced at the end of 2011 do not play a role in balancing the interests of the Chinese film box office and hindering the healthy development of China's film industry. Wu also suggests that China's film industry should advance its reform and innovation, and balance the interests of Chinese filmmakers and cinemas. Yu (2012) analyzes the game among film companies, banks and advertisers with game theory, revealing the restriction and interaction between different investment and financing bodies in the film industry.

The existence of Hollywood in China is an important issue in studying the film history of the country. Based on the previous studies (Chu 2011; Wu 2013; Yu 2012), this article will explore and explain the relationship between China's film industry and Hollywood with game theory. 


\section{China's entry into WTO and Hollywood's into China}

Due to its large population and constantly increasing economic strength, China plays a significant role in today's globalization. Hence, China has an important strategic position in America's unipolarization strategy. The Chinese market has long been valued by Hollywood. Based on how Hollywood has been treated in the country, the past six decades are divided into three stages. The first stage is from 1949 to 1977 , which is China's planned-economy period. The second is from 1978 to 1993, which is the transitional period when China underwent the reform and opening-up. The third is from 1994 to 2009, which is the period for China's movie market to open to Hollywood.

\subsection{The planned-economy period (1949-1977)}

The founding of the People's Republic of China by the Communist Party of China (CPC) in 1949 marked the decline of Hollywood films in the country. Moreover, the outbreak of the Korean War directly led to the ousting of American movies.

From the early 1950s to 1978, the year of reform and opening up, the Chinese film industry was managed by the government and the national films were highly regulated by the China Film Group Corporation (He 2012: 22). Moreover, under the influence of the diplomatic principles and film policy of "favoring the USSR more than the US", China imported many films from the former Soviet Union and some other socialist countries, threatening the survival of Hollywood movies in the country. Xia Yan (1960), the then Deputy Minister of Culture, roughly summarized the history of American movies by saying that "pornography, terrorism, anti-Soviet Union, anti-China, anti-socialism have been the major themes of Hollywood movies." He described the American movies as "depressed and declined".

Starting from November 15, 1950, when the Korean War broke out, American films were completely banned in mainland China (Xia 2002). On January 3, 1951, The People's Daily published an article declaring that China had almost "swept out American movies that had poisoned the Chinese people" (Xia 2002: 19). During the 30 years from 1951 to 1981, only one American movie was exported to mainland China, which is Salt of the Earth (Biberman 1954). It is a 1954 American drama film written by Michael Wilson, directed by Herbert J. Biberman and produced by Paul Jarrico. ${ }^{(1)}$ Ironically, this film was once banned by the US government because it was written, directed and produced in 1954 by members of the original "Hollywood Ten" who were blacklisted for refusing to answer to Congressional inquiries on First Amendment grounds. However, this drama film is one of the first pictures to advance the feminist social and political point of view. Its plot centers on a long and difficult strike, based on the 1951 strike against the Empire Zinc Company in Grant County, New Mexico. In the film, the company is identified as "Delaware Zinc" and the setting is "Zinctown, New Mexico." The film shows how the miners, the company and the police react during the strike. Therefore, it was considered "progressive" by the Chinese government (Su 2010: 41).

3.2 The transitional period of reform and opening-up (1978-1993)

In December 1978, the Third Plenary Session of the Central Committee of the CPC decided that 
China's economic construction should be the focus of the Party's work. The film studios in China began to implement the new policy of "accounting independently, taxing to the state and self-financing under the guidance of the national plan". Foreign capital thus had a chance of re-entering into China and restarted the game with the Chinese film industry.

In the early 1980s when China opened the door to the outside world and launched the economic reform, a small number of American films had passed the strict censorship into China. In 1981, China and the United States hosted the first film exhibition after 1949. The four American movies including Shane (Stevens 1953), Singing in the Rain (Freed 1952), Guess Who's Coming to Dinner (Kramer 1967), Black Beauty (Nosseck 1946) and Snow White (Disney \& Hand 1937) were shown in China' five cities. Thereafter, out of dozens of imported films, there would always be several American films shown in China every year.

However, China's economic reform and political reconciliation with the United States failed to make a large number of Hollywood films accessible to Chinese cinemas. In dealing with Western private companies, the Chinese government persisted in purchasing films with a flat fee instead of revenue sharing, but Hollywood preferred the latter. The stalemate between the Motion Picture Association of America (MPAA), the trade association of America's biggest studios, and the China Film Export and Import Corporation (China Film), the only one in the then China that had the authority to decide the importation of foreign films, lasted until the mid-1980s when Hollywood began to look more seriously at the economic reform in China as a chance for its entry into the Chinese film market. For the first time since 1949, the two major American film companies, Paramount Pictures and Universal Pictures, distributed American films in China. The two studios signed an agreement with the China Film Corporation in Beijing, which controls the release and distribution of all films in China. According to the agreement, American films were to be shown in 3,000 major cinemas and 20,000 smaller urban and rural cinemas in the country. Ticket admissions in China were estimated by China Film to be about 25 billion in 1985. Not only did the Chinese flock to cinemas, but the country had more than 160,000 projection units, which were groups of people who traveled around the countryside showing films in informal settings. In some places admission charges were paid in commodities (Fabrikant 1986: 1, 4). In 1985, China together with the MPAA organized a festival of five American films, of which the most popular were Kramer vs. Kramer and On Golden Pond. The other films were Coal Miner's Daughter, Star Wars and The Turning Point. Noting the strong audience response to Kramer vs. Kramer and On Golden Pond, Mr. Paul, who spent several months in China, said that "Those films involve family issues and respect for elders and people could relate them to the problems and issues in the family structure" (ibid.: 4).

In 1986, China established a cooperative tie with the Music Corporation of America and contracted to import films from it for several years. Meanwhile, China also sought to cooperate with Columbia Corporation, 20th Century Fox Corporation, and Disney, and began to show their movies on satellite TV channels. The same year witnessed the importation of famous American films into China such as Spartacus (Kubrick 1960), Roman Holiday (Nosseck 1987) and Love Story (Hiller 1970). In 1988, China held an exhibition of early American films, showing about 31 produced around the 1930s. However, the Sino-American cultural exchanges were temporarily interrupted from 1990 to 1993 because of the 1989 Tiananmen Square Incident ( $\mathrm{Su} 2010:$ 41-42). 
From 1985 on, the number of co-productions rose sharply in China. Foreign capital started to become an influential economic power in the Chinese film market. The numbers of the imported films from 1978 to 1993 are shown in Figure 1.

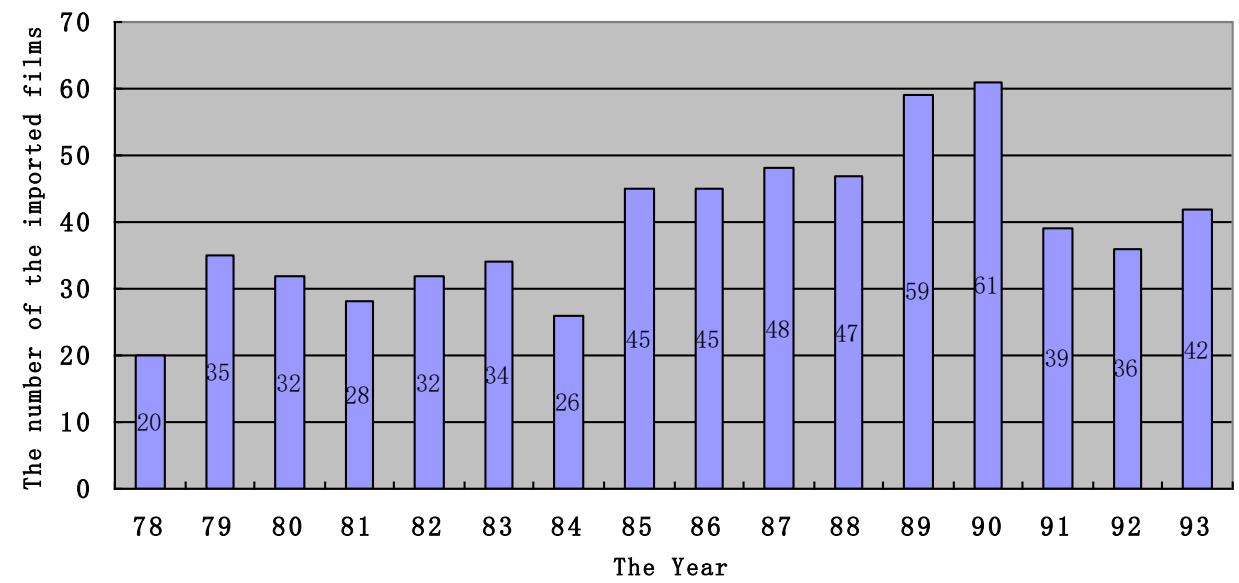

Figure 1: The numbers of imported films, 1978-1993 (Li 2010: 42)

As for these imported films, we have made a statistics on the top seven countries from which China had imported films from 1978 to 1993 (See Table 1).

Table 1: Ranking of countries from which China imported films (Li 2010: 42)

\begin{tabular}{||l|l|l|l|l||}
\hline RANKING & COUNTRY & $\begin{array}{l}\text { NUMBER OF } \\
\text { IMPORTED } \\
\text { FILMS }\end{array}$ & $\begin{array}{l}\text { NUMBER } \\
\text { CO-PRODUCED } \\
\text { FILMS }\end{array}$ & PERCENTAGE \\
\hline 1 & America & 114 & 2 & $18.2 \%$ \\
\hline 2 & Japan & 83 & 5 & $13.2 \%$ \\
\hline 3 & France & 58 & 8 & $9.2 \%$ \\
\hline 4 & Britain & 38 & 3 & $6.1 \%$ \\
\hline 5 & North Korea & 37 & 0 & $5.9 \%$ \\
\hline 6 & Romania & 37 & 0 & $5.9 \%$ \\
\hline 7 & Russia & 34 & 2 & $5.4 \%$ \\
\hline
\end{tabular}

It can be seen from Table 1 that the American films are in the first place in all the countries from which China imported films.

A clearer and more visual trend of imported American films from 1978 to 1993 can be presented in Figure 2. 


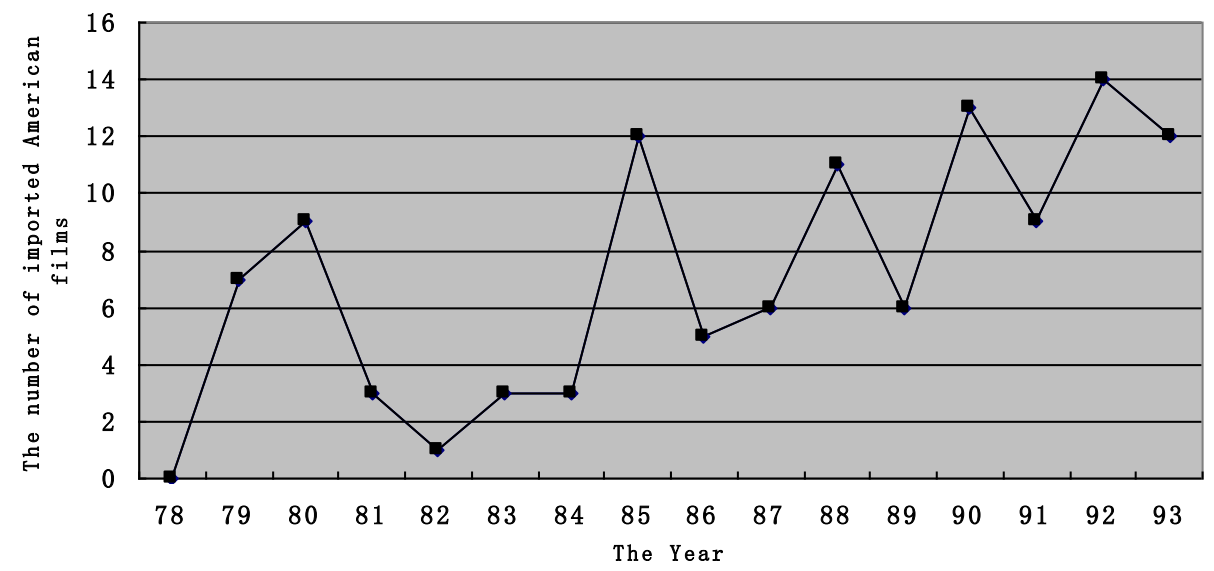

Figure 2: The trend of imported American movies, 1978-1993 (Li 2010: 44)

3.3 The opening period of China's film market to the West (1994-2009)

In the 1990s, the Chinese film industry began to carry out the reform, completely breaking the "one-stop" monopoly mechanism of film production, distribution and screening and starting the transition to the market-economy system. China's film industry and film-makers in the transitional period had to face the market directly, unable to extricate themselves out of financial difficulties and credibility crisis. Thus, there was an urgent need for Chinese films to get a long-term investment in the overall process from production to screening (Rosen 2003: 45).

In 1994, China began to introduce foreign movies, especially Hollywood movies in the form of "revenue-sharing films" which are the ones whose box office revenue will be shared by China and Hollywood according to a certain proportion. This governmental measure not only solved the financial difficulties for Chinese films, but also greatly stimulated the competition between China's film industry and Hollywood (He 2012: 113, 115). In 1995, China decided to introduce 10 films from abroad which "represent the highest achievements of the world's motion picture arts and technology" (Li 2008: 21). In some sense, Hollywood helped invigorate China's film market. But at the same time Chinese national films got a great shock, facing an unprecedented crisis (Li 1997).

On November 15, 1999, China and America reached a bilateral agreement on China's accession to the World Trade Organization (WTO). The Chinese government promised to allow foreign companies whose foreign investment accounts for over $50 \%$ of the shares to engage in the construction and operation of cinemas in China after two years of its accession to the WTO. China would introduce 10 to 15 foreign films annually, most of which are Hollywood products. From 1994 to 2000, the China Film Group Corporation imported a total number of 267 films including revenue-sharing films and buyout films, showing little change in the average annual import volume compared to the previous 16 years and averaging 38.1 films per year. Moreover, the number of countries from which China imported films decreased from 43 to 18, excluding Hong Kong. As for revenue-sharing films, besides America whose 49 Hollywood movies were introduced by China, only two other countries exported their films to the country, accounting for only $5.6 \%$ of the total number of countries (Wang 2008). 
Table 2: Ranking of countries/regions of revenue-sharing films, 1994-2000 (Li 2010: 47)

\begin{tabular}{|l|l|l|}
\hline Country/Region & Number & Percentage \\
\hline America & 49 & $68.3 \%$ \\
\hline Hong Kong & 18 & $25.1 \%$ \\
\hline Britain & 3 & $4.2 \%$ \\
\hline France & 1 & $1.4 \%$ \\
\hline
\end{tabular}

It can be seen from Table 2 that the revenue-sharing films are mainly imported from America, so are the imported buyout films (See Table 3).

Table 3: Ranking of countries/regions of buyout films, 1994-2000 (Li 2010: 47)

\begin{tabular}{|l|l|l|l|}
\hline Ranking & Country/Region & Number & Percentage \\
\hline 1 & America & 72 & $36.7 \%$ \\
\hline 2 & Italy & 21 & $10.7 \%$ \\
\hline 3 & France & 20 & $10.2 \%$ \\
\hline 4 & Britain & 18 & $9.2 \%$ \\
\hline 5 & Germany & 11 & $5.6 \%$ \\
\hline 6 & Japan & 11 & $5.6 \%$ \\
\hline 7 & South Korea & 10 & $5.1 \%$ \\
\hline
\end{tabular}

In 2002, eight years after the return of Hollywood films to China, Nanfang Weekend ran a special edition entitled "An Elegiac Dedicated to the Invasion of Hollywood Films". The article reviewed the eight-year journey of Hollywood films in China and the corresponding performance of China's national films, declaring that the Chinese film market had been conquered by Hollywood (Xia 2002). A radical film critic named Dai Jinhua, said in an interview with the reporter of Nanfang Weekend, "It has shown that this eight-year invasion by Hollywood films has stricken a deathblow to China's national film industry. Moreover, the situation is going to be worse with China's re-entry into the WTO. If I once predicted "the wolf is coming," I now believe the wolves are coming" (Cited in Xia 2002: 19). On February 17, 2012, China and America signed the "Memorandum of Understanding between China and the United States on Solving the Problems on WTO Films" in Los Angeles, which was later called the "Sino-American Film Agreement". This agreement means that the Chinese film market will be more open (Zhao 2013: 158).

However, some measures were taken to restrict the expansion of Hollywood in the country. For example, on January 1, 2004, the Chinese government promulgated the "Provisional Regulations on Foreign Investment in Cinemas", whose Article IV is as follows: As for Sino-foreign invested cinemas, the proportion of registered capital of Chinese investment in the joint venture should cover no less than $51 \%$. 2) These measures help promote the development of the domestic film market, enhancing the domestic movie box office. 


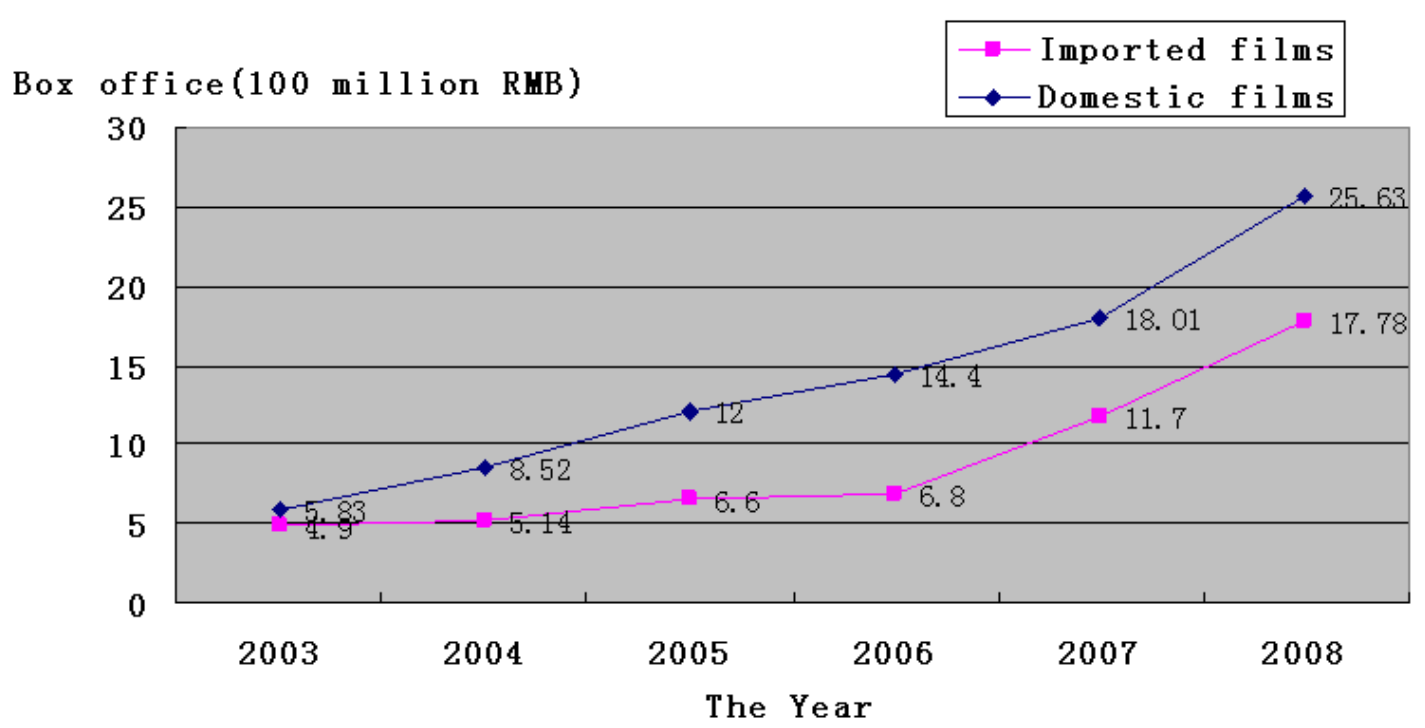

Figure 3: Box office revenues of domestic and imported films, 2003-2008 (Li 2010: 52)

It can be seen from Figure 3 that, for the six consecutive years, the box office revenues of the domestic films and revenue-sharing films show an upward trend, while the growing trend of the former is always higher that that of the latter.

In summary, in the planned-economy period, China was blocked and contained by the imperialist countries led by the United States. As the other player of the game, China chose the best gaming strategy by adopting the diplomatic principle of "favoring the USSR more than the US" and the similar film policy, reducing the profit of American films in China. As a result, Hollywood movies faced enormous difficulties to survive in the country. The reform and opening-up period gives rise to the re-entry of Hollywood into China. With the charm of American films and the efforts of the American government, Hollywood movies snatched the lion's share in China's market of imported films. With China's accession to the WTO, Hollywood exported more and more films to China, making a serious impact on China's national film industry. In order to protect its national film industry and reduce the loss in the game between American and Chinese film industries, China has adopted some gaming strategies to resist Hollywood and gain more payoffs.

\section{China's restriction of Hollywood films}

Game theory is based on the premise that no matter what the game, no matter what the circumstances, there is a strategy that will enable the player to succeed. In order to reduce the influence of Hollywood and protect the national film industry, the Chinese film industry adopted the following gaming strategies: the film quota system, the protection month, translators' interventions, and criticisms from film-makers and scholars.

\subsection{The film quota system}

In general, the film quota system is one of effective measures to restrict the imports of foreign films. It is also called "the system of showing domestic films with obligation". Here, the word "obligation" does not mean "free of charge", but that Chinese cinemas are obliged to show local Chinese films, as has been done in other countries such as South Korea. Every country has its own 
regulations to protect the domestic films according to the specific conditions (Chen 2006: 3). The Great Britain is the first country to introduce the film quota system, followed by South Korea, Brazil, Pakistan and Italy. Take South Korea as an example. In order to protect its national film industry, South Korea established its own film quota system. It is mandatory that each cinema should devote 146 days to showing national films. The implementation of such a system can guarantee a steady rise of the domestic film box office, and reduce the impact of foreign films on the local ones.

China has a similar film quota system which requires that each year two-thirds of the time and space must be given to Chinese domestic films (Wei 2006: 18). The movie projectionists are asked to keep a minimum number of film screenings. Facing the impact of Hollywood on China, many Chinese people choose to see Hollywood movies instead. Especially when the off-season of local film release comes, many Hollywood films take the opportunity to occupy the Chinese film market, which threatens the domestic film industry. As a result, Hollywood can only export less than 10 films to China, getting only $\$ 20$ million in revenue. According to $20^{\text {th }}$ Century Fox and other studios, American revenue-sharing films in China only got about $12 \%$ of box office revenues (Yin and Xiao 2002: 113).

With China's entry into the WTO in 2000, the quota of imported films had to be increased to 20 foreign films. As a further constraint, each of the 20 foreign films first had to "undergo lengthy rounds of review and censorship". That means months will pass before the imported film makes its debut in other countries (Ting 2007: 14-16). China remains in a favorable position in preventing a short-term Hollywood domination of its market. The WTO rules provide the continued protection of the Chinese film industry. Just as Canada and France continue to protect their cinemas against US domination, China will be able to subsidize its film producers and limit foreign films shown in cinemas or on television. China is more likely to strengthen its measures compared to France or Canada. Facing the restriction policies of the Chinese government, Hollywood studios are not likely to be able to manipulate the Chinese market as freely as they wish, nor to make as many profits as they wish.

Though the film quota system effectively reduces the impact of Hollywood on the national film box office, it should be handled properly because Hollywood can promote the development of local films as well. The Chinese films can be improved by learning from Hollywood with special reference to its technologies. Hence, the two players of the game can maximize each other's advantages and gain the maximal benefits.

\subsection{The protection month}

In addition to the film quota system, foreign films are barred in Chinese cinemas during holidays and other peak periods. There is a special period of time which is called the "protection month". It was in some sense created on the basis of the administrative order so as to protect the local films, serving as a barrier to the introduction and releasing of imported films and also as an umbrella for the local films. ${ }^{(3)}$ The protection month is indeed a verbal notification by the National Film Board in 2004 in the hope of supporting the local films. ${ }^{\oplus}$ It refers to a month-long period roughly from June 10 to July 10 when the revenue-sharing films are not encouraged to show in cinemas. Therefore, unlike their American counterparts, during the blackout periods, Chinese audiences do not have a 
chance to enjoy the latest Hollywood blockbusters in cinemas because of the governmental restrictions.

The protection month is aimed to help domestic films reach the expected share in box office. As a result, Chinese film box office revenues soar in this very month, while those of imported films drop sharply on the whole. Besides, the withdrawal of foreign films from China's market is also an important means of the protection month. ${ }^{(5)}$ Though the protection month plays an important role in the development of the local films, it is not omnipotent. Only by improving their quality can Chinese films gain more payoffs in the game with Hollywood. A good case in point is the China-made low-cost film Lost in Thailand which had gained the box office revenue of more than one billion yuan (RMB). Under the encouragement of this film, from the end of 2012 to the first half of 2013, more and more Chinese films gained great payoffs in the direct confrontation with Hollywood movies.

\subsection{Translators' intervention}

Translation plays an important role in resisting the expansion of Hollywood into China. Guo Jianzhong (2000) holds that translation is a game in which the translator is the player. Translators obey the norms of rule-governed semiotics; at the same time they can change and create the rules of the game. Hence, translation becomes a game of knowledge-possessing, creativity and decision-making. As a player, the translator manipulates the source text through choice of translation strategies, especially in use of domestication.

Take the translation of Disney's Mulan, for example (Xu and Tian 2013). Disney misappropriated Chinese culture, and the Chinese legend about Mulan was wantonly tampered in order to cater to American audiences. Confronted with the distortion of Chinese culture by Disney, namely one player of the game, China as the other player reacted to it via translating. When translating Mulan into Chinese, Chinese translators, in many cases, restored the original Chinese culture which had been Americanized in the film. In the Chinese translation of Disney's Mulan, the typical game models such as the Prisoner's Dilemma and Nash Equilibrium are used to conduct cultural restoration.

Mulan, a 1998 Disney-produced animated film, draws on the Chinese legend of Hua Mulan to construct its plot framework, achieving tremendous success with children around the world. It was introduced back to China in a dubbed version in 1999. The production and translation of the film involves two encounters between American and Chinese cultures in both Disney's adaptation of the Chinese legend of Mulan and the Chinese translation of Disney's Mulan. The Chinese version of the film was produced by Disney Character Voices International, Inc. in the Beijing Film Studio, and distributed by Beijing-based CAV Thakral Home Entertainment Co., Ltd. The translator of its Chinese version is Tu Weizhong (涂卫中). This article will focus on the script translation of the film to look at the employment of domesticating translation strategies which are aimed to restore the original Chinese cultural context, thus helping illustrate the translator's intervention.

In the game model of the Prisoner's Dilemma, the player uses every possible means to betray, thus making a non-cooperative equilibrium, that is, Nash Equilibrium. In audiovisual translation, the 
betrayal strategy refers to the domesticating translation strategy. Domesticating methods are the ones that try to bring the source text as close as possible to the target language and culture. As far as the rendering of Disney's Mulan is concerned, the methods are used in cultural restoration which means cultural deformations produced by cultural adaptations come back to their original forms. Cultural restoration relates not only to linguistic forms but also to semantic content and contextual atmosphere. The translator of the film uses such domesticating methods as diction (choice of words), generalization (which makes a specific thing general or abstract), substitution (which substitutes one thing for another), semantic addition (words are added to reproduce the original meaning), semantic deviation (in which the target text deviates from the original meaning), free translation (which reproduces not the literal but the deep meaning of the source text), and so on, to reconstruct the authentic cultural milieu. Let us look at some examples.

(1) General Li: Your Majesty, the Huns have crossed our Northern border. 李将军: 启禀皇上, 匈奴已越过北方边界。

(2) Chi Fu: Yes, Your Highness.

赐福: 臣在。

(3) Chi Fu: Citizens, I bring you a proclamation from the Imperial City. The Huns have invaded China!

赐福: 乡亲们! 我从京城带来皇上的谕令, 匈奴侵犯中原!

(4) Chi Fu: The Fa Family.

Mulan: No.

Fa Zhou: I am ready to serve the Emperor.

赐福: 花家接旨。

木兰: 不。

父亲：草民已准备为国效劳。

(5) Emperor: My children, heaven smiles down upon the Middle Kingdom.

皇上：我的子民们，感谢老天爷照顾京城。

(6) General Li: Forgive me your Majesty, but I believe my troops can stop him.

Emperor: I won't take any chances, General. A single grain of rice can tip the scale. One man may be the difference between victory and defeat.

李将军: 恕臣直言, 我的重兵能够阻挡单于。

皇上: 我们不能够冒这个险, 将军。小兵也会立大功。有时候不起眼的人也是胜败关键。

(7) Fa Li: You must go after her. She could be killed!

Fa c: If I reveal her, she will be.

Grandma Fa: Ancestors, hear our prayer: Watch over Mulan.

母亲：你必须把她追回来，这可是欺君之罪啊！

父亲: 万一暴露了, 是要杀头的呀!

婆婆：列祖列宗, 求求你们, 保佑木兰吧!

The term "Your Majesty" was and is used to address a king or queen in England. Its use in example (1) colours the dialogue with English culture. But in the Chinese version it is rendered into “启禀皇上” (qi bing huang shang), which immediately brings the audiences back to ancient China to watch a dialogue between the emperor and his subject. The translation of "Yes, Your Highness" into “臣在” (chen zai) in example (2) reconstructs a similar situation of conversation as if it were 
taking place in feudal China's imperial palace. Here, the restoration of the authentic Chinese cultural context is based on diction. The translation does not only use the language used by ancient Chinese people but also chooses the language which is most appropriate to the very context of situation. “陛下” (bi xiang) and “是的, 陛下” (shi de, bi xiang) can be used to translate “Your Majesty" and "Yes, Your Highness" respectively. Although they may be used by ancient people, they are contextually improper. Another good case in point is the choice of “乡亲们” (xiang qing $m e n$, folks) and “谕令” ( $y$ u ling, emperor's order) to translate "citizens" and "proclamation" in example (3). “Citizen” is often translated into “公民” ( gong min) and “proclamation” into “布告” (bu gao) or “声明” (sheng ming) today. But these “modern” translations will make audiences of the film lose the sense of the times in which the story is set. However, the use of “乡亲们” and “谕令” does not only agree with the ancient Chinese language but also makes the utterance very Chinese-specific.

The name of the character "Chi Fu" in example (3) is meaningless to English speakers, but its Chinese version “赐福” ( $c i f u$ ) has a meaning which is traditionally favourable to Chinese people. “赐” means “give”, “福” means “blessing” and the whole expression “赐福” means something like "May God bless you" in Western culture. The phonetic mutation "Fa" in example (4) is restored as the orthodox "Hua" (花) in the translation and "I" in the same example is not literally translated into “我” (wo) but into “草民” (cao min, humble person), which is quite in agreement with the cultural context of the day.

The word "children" in example (5) is not literally translated into “孩子们” (hai zi men) but into “子民” ( $z i \mathrm{~min}$, children and people) because emperors tend to use the latter rather than the former to address their people in feudal China. This kind of translation expands the scope of reference of "children" and the method may be labelled generalization. The expression "A single grain of rice can tip the scale" in example (6) is translated into “小兵也会立大功” (a common soldier can also achieve great military merit) instead of the literal rendering “一粒稻米也能使天平 倾斜”. This is a kind of free translation which focuses on the deep meaning of the source language and can make the verbal context more coherent. The "man" in the same example is translated into “不起眼的人” (unimportant person) in which “不起眼的” (unimportant) is a kind of semantic addition and seems to allude to Mulan. Free translation is also used in translating "She could be killed" and "hear our prayer: Watch over Mulan" in example (7), which are translated into “这可是 欺君之罪啊” and “求求你们, 保佑木兰吧” respectively. A literal rendering of “She could be killed” is “她可能被杀头”, but “这可是欺君之罪啊,” which means “this is the crime of deceiving the emperor," is the more probable utterance in the very context that the film has constructed. Likewise, the literal rendering of “hear our prayer: Watch over Mulan" into “听听我们的祈祷: 看 护好木兰” is not what Chinese people would utter on that occasion. Instead, they would more probably say “求求你们, 保佑木兰吧” (Beg you, please bless and protect Mulan).

In a broad sense, the choice of strategies for rendering Hollywood films is not only Chinese translators' choice of gaming strategies, but also that of China resisting Hollywood films. In the case of Mulan, the Chinese translator has made some adjustments in order to help the target audiences understand the film, reducing the impact of Hollywood upon Chinese culture and people. 


\subsection{Criticisms from film-makers and scholars}

The sweeping Hollywood imports and the unprecedented impact on the domestic market caused extensive concerns amongst filmmakers, film critics, and left-wing intellectuals in mainland China. While film distributors cheered market revitalization and economic gains, and ordinary moviegoers embraced Hollywood blockbusters and welcomed competition from Hollywood, the majority of China's filmmakers and left-wing intellectuals strongly opposed the importation of Hollywood movies, and advocated the protection of the indigenous film industry. Hundreds of college students from the Beijing Film Academy, the most prestigious college in China for film directors, cinematographers, actors, and actresses, even jointly issued an open letter calling for "resisting Hollywood" (Song 1995). They argued that "Hollywood has always been the vanguard of American transnational capital" (Dai 1995: 8). They were worried that Hollywood would reap huge economic profits from China and then conquer the entire Chinese film market; as a result, China's national film industry would be completely destroyed. Furthermore, they were deeply concerned that the American way of life and Western values represented by Hollywood movies would be instilled in the minds of Chinese people, endanger Chinese cultural tradition, and undermine national identity. Therefore, they believed that safeguarding the national film industry should be the government's obligation and top priority (Su 2010: 44-45).

Hollywood's global expansion in China inevitably met with criticisms from the Chinese show business. Some Chinese scholars and film-makers including directors and producers made some reviews on the professional production, narrative subjects and cultural expansion of Hollywood in order to protect the local film market. Their reviews may serve as a guideline for domestic audiences to accept Hollywood films and they also can affect Hollywood box office returns in China. A report in Oriental Morning Post entitled "In Hollywood-free days we live very happily", points out that "in the first half of this year, the Chinese film box office flopped... some relevant authorities had to adopt the protection month, hoping the domestic film industry can have a comeback. Until now, nearly half of the protection month has passed, and some Chinese films have achieved a breakthrough in their box office" (Kang 2012: 14). Chen Kaige, the director of the film Caught In The Web, also attributed their high box office to the protection month (ibid.).

\section{Discussion and implications}

According to game theory, the two players of a game tend to adopt a gaming strategy to increase their payoffs as many as possible. Global expansion is a gaming strategy of Hollywood to gain its maximal payoff. The resistance against Hollywood is China's gaming strategy to increase its payoff. In the localization of Hollywood in China, the American narrative strategies and marketing concepts are learned by the country, which promotes the development of the Chinese film industry. Therefore, we cannot always resist Hollywood; instead we should adopt some rational measures to strengthen the domestic film industry with the aid of Hollywood. As a result of the game, there will be a balance between China and Hollywood, thus leading to a diversified film culture.

\subsection{Necessity of the film quota system}

In the game between Hollywood and the Chinese film industry, it is necessary to adopt the film quota system to reduce the impact of Hollywood and ensure the survival and development of the industry. South Korea adopted a film quota system to play the game with Hollywood and stipulated that at least 
146 days a year should be devoted to domestic films in local cinemas. Even though the American government criticized that the film quota system deviated from the principles of free trade, South Korea strongly called for "cultural exception", in order to protect their domestic film industry (Paquet 2002). In 2000, the South Korean government decided to consider the negotiation on the abolition of the film quota system only if their domestic films released accounted for more than $40 \%$ of the market. Surprisingly, the domestic films released accounted for 50\% of the total films in 2002, but South Korean filmmakers and distributors still persisted in their film quota system.

The film quota system is necessary, for it is unwise to combat with Hollywood if the domestic film industry is not strong enough financially and technologically. A good example is Mexico. Ever since the Mexican government terminated the film quota system in 1993, Mexican film production had plummeted from 100 films per year before 1990 to 30-40 films per year after 1993. Since 1993 when the Mexican and American governments signed a bilateral trade agreement and the film quota system was abolished, the Mexican domestic film industry in the subsequent three years had met with a devastating blow (Wildman 1995).

It seems that the examples above indicate the absolute necessity to adopt the film quota system for China to protect its local film industry. China's national film industry is at a competitive disadvantage in Hollywood's global expansion. China should learn from other countries. In other words, China should maintain the film quota system, persisting in showing a considerable number of its local films. Moreover, the Chinese film industry should gain the financial support from its government. Of course, when the Chinese film industry is powerful enough to compete with Hollywood, it is possible to regulate and abolish the system.

\subsection{Globalization, localization and issue of cultural diversity}

In the game between the Chinese film industry and Hollywood, the two players can maximize their payoffs if they can absorb each other's cultural essence to complement their own culture. And by extension, the game between Chinese and Hollywood films implies that other countries can also adopt the same gaming strategy to maximize their payoffs when their industry enters into the game of cultural globalization. In this way the game will not be a lose-lose but a win-win one, accelerating the ongoing global exchange of cultural integration and globalization.

A Japanese scholar named Hirano Kenichiro holds that the more frequent cultural contacts between countries are realized, the more diversified cultures tend to be (See Jia 2006: 107). Although the US-led Western countries are in a dominant position in the economic globalization, the cultural globalization not only complies with the rules of the market economy, but also is restricted by some factors such as non-market factors, non-cultural capital and non-Western powers. These factors have characterized the cultural globalization with multi-dimensions and diversity, which is called hybrid culture (Tomlinson 2002). From the point of view of game theory, a hybrid global film culture is the requirement of the balance of the game. If the world's major cultures as players of the game passively or actively absorb other film cultures, they may be assimilated to some degree in a single game or a few rounds of games. However, in the long run, it can be expected that countries like China may develop their national film industry by absorbing the essence of other film cultures and incorporating it into their own cultural system after repeated games. 
In the era of globalization, a country's film industry cannot expect to rely on its own market to survive and develop. The penetration of foreign studios into China not only refers to their film products entering China, but also to the foreign investment of capitals in China's film-making, resulting in an impact on Chinese film-making quality and its operation philosophy. The technological progress in this regard can be expected. But cultural differences between China and Western countries require the localization of foreign elements including Hollywood culture. This kind of localization can learn quite a lot from the advantage of Chinese national films. Of course, to protect the local film culture should not be an excuse for China to enter the cultural globalization. The threat is not from Hollywood. The point is that China's film industry must be reformed to survive and develop. Otherwise, even without the entry of Hollywood into China, the Chinese film industry would have nowhere to go, for there will be new media such as television, mobile phone and so on to shunt the audiences.

Finally, we should be committed to creating a pattern of diversified world film cultures. There are several steps to follow. Firstly, whether China and Hollywood adopt absorbing or resisting strategies should depend on their own benefits. Secondly, realizing the balance of the game between China and Hollywood can be a win-win situation for the two players. In other words, to maximize their own payoffs is to maximize the payoffs of the whole. Thirdly, there exists rationality in the game between China and Hollywood. In order to maximize its own payoffs in political, economic and cultural fields, a country must adopt the rational cultural strategy. Lastly, the Chinese film industry and Hollywood may establish a contractual relationship in their competitive and cooperative game. In a word, on the one hand, China needs to resist Hollywood films; on the other, it can absorb and learn from Hollywood to make its own place in its cultural globalization.

\section{Conclusion}

It is noted that game theory cannot be regarded as a universal one in studying cultural globalization, for it has its dogmas and limitations in the study of social sciences. This article explores the possibility of applying game theory in the field of cultural globalization, aiming at describing the clashes, compromises and co-operations in cultural globalization with the basic idea of game theory. The article suggests that game theory can provide a broad and useful guiding framework for analyzing the strategic interactions between the Chinese film industry and Hollywood. It can be argued that the game between China's film industry and Hollywood is a dynamic and repeated game of non-cooperation, negotiation and competition for the six decades since the founding of the People's Republic of China. As a result of this ongoing game, both parties co-existed through retention of cultural diversity and Hollywood's expansion in China. It is suggested that the research findings in this study be further tested in the games between other countries and Hollywood.

\section{Notes}

(1) See http://en.wikipedia.org/wiki/Salt_of_the_Earth.

(2) "Provisional Regulations on Foreign Investment in Cinemas (2003)" was issued by the State Administration of Radio Film on November 25, 2003.

(3) “An embarrassing 'Protection Month': Incapable of Shouting” was published on June 4, 2013. It can be retrieved at http://et.21cn.com/gundong/etscroll/2012/06/04/12050738.shtml.

(4) "Whether There Is the 'Protection Month' or Not: Looking at Its Background" was published on 
June 6, 2012. It can be retrieved at http://ent.163.com/special/bhy/.

(5) "Withdrawal of Films + Internal Friction: "The Protection Month"” was published on June 8, 2013. It can be retrieved at http://enjoy.eastday.com/c8/2013/0608/472820860.html.

\section{References}

Biberman, H. J. (1954). Salt of the Earth. United States: Independent Productions.

Chen, Y. (2006). The opening of culture from the evolution of the Korean film quota system. Movie Review, (23): 3-6.

Chu, T. (2011). Collision of Chinese and Western cultures and cultural globalization from the perspective of game theory. Culture Journal, (4): 75-79.

Dai, J. (1995). How I view Hollywood. Beijing Youth Daily, October 9.

Duke, P. F. (2000). Great wall falls. Variety (electronic version), May 25.

Esmaeili, M., et al. (2009). A game theory approach in seller-buyer supply chain. European Journal of Operational Research, (195): 442-448.

Fabrikant, G. (1986). Hollywood returns to China. New York Times, February 7.

Frey, E. (2010). Evolutionary game theory: theoretical concepts and applications to microbial communities. Physica A, (389): 4265-4298.

Gorlee, D. L. (1994). Semiotics and the Problem of Translation, with Special Reference to the Semiotics of Charles S. Peirce. Amsterdam and Atlanta, GA: Rodopi.

Greenberg, J. (1986). Par, universal to distribute pics in China. Variety, February 12.

Gong, J. (2009). An approach of game theory to journalism and communication studies. Journalism Lover, 2009, (12): 9-10.

Greenfield, L. (1992). Nationalism: Five Roads to Modernity. Cambridge, MA: Harvard University Press.

Guo, J. (2000). Contemporary American Translation Theory. Wuhan: Hubei Education Press.

He, C. (2012). China's Film Industry and Its Policy. Beijing: Xinhua Publishing House.

Hymer, S. (1976). The International Operations of National Firms. Cambridge, MA: MIT Press.

Jia, F. (2008). On the roots of diversified culture. Qiu Suo, (6): 107-109.

Kang, M. (2012). On the protection of domestic films. Cinema World, (8): 14-15.

Kindleberger, C. (1969). American Business Abroad. New Haven, CT: Yale University Press.

Law, W. \& Pan, S. (2009). Game theory and educational policy: private education legislation in China. International Journal of Educational Development, (29): 227-240.

Li, D. (2008). Prospects of the cultural globalization and the building of a harmonious world. Journal of Renmin University of China, (1): 105-111.

Li, J. (2010). The Study of Film Imports with the System Evolution in the New Era. PhD thesis.

Jinan: Shandong University.

Li, M. (1997). National films: its anxiety and its way out. Legal Daily, (4): 56-59.

Li, S. (2011). Regional competition and sustainable development: a game theory model for tourism destinations. European Planning Studies, (4): 669-681.

Li, Y. (2008). The survival of Hollywood - rethinking the four properties of American films. In Lu,

Y. \& Li, Y., Focusing Hollywood: Diversities of the "Silver Dream". Beijing: Beijing

University Press. 35-47.

Matusitz, J. (2010). Disneyland Paris: a case analysis demonstrating how glocalization works. 
Journal of Strategic Marketing, (3): 223-237.

Paquet, D. (2002). Korean cinemas exceeding local quota requirements. Accessed November 11. http://www.screendaily. com/story.asp?storyid=9046.

Qi, L. (1999). Hollywood, films and politics. Contemporary Era, 139: 19-29.

Robertson, R. (2007). Glocalization. In R. Robertson \& J. A. Scholte (eds), Encyclopedia of Globalization. New York: Routledge. 524-552.

Rosas, A. (2010). Evolutionary game theory meets social science: is there a unifying rule for human cooperation? Journal of Theoretical Biology, (264): 450-456.

Rosen, S. (2003). Wolf forcing front: 1994-2000 Hollywood and Chinese film markets. Journal of Beijing Film Academy, (1): 45.

Sigismondi, P. (2009). Hollywood piracy in China: an accidental case of US public diplomacy in the globalization age. Chinese Journal of Communication, (3): 273-287.

Sinclair, J. (1990). Neither west nor third world: the Mexican television industry within the NWICO debate. Media Culture and Society, (3): 343-360.

Song, G. (1995). A look at film the circle in 1994. The Theater \& Film News, February 10.

$\mathrm{Su}, \mathrm{W}$. (2010). To be or not to be: China's cultural policy and counterhegemony strategy toward global Hollywood from 1994 to 2000. Journal of International and Intercultural Communication, (1): 38-58.

Ting, O. (2007). Pirates and the Orient: China, film piracy, and Hollywood. Jeffrey S. Moorad Sports Law Journal, (2): 1-46.

Tomlinson, J. (2002). Globalization and Culture. Nanjing: Nanjing University Press.

Wan, J. \& Kraus, R. (2002). Hollywood and China as adversaries and allies. Pacific Affairs, (3): 419-434.

Wang Y. (2008). Foreign films bombarding the Chinese screen. Yanzhao Evening News, December 25. http://www.sjztour.com.cn.

Wei, P. (2006). On the film quota system. Movie Review, (14): 18.

Wildman, S. (1995). Trade liberalization and policy for media industries: a theoretical examination of media flows. Canadian Journal of Communication, (3): 367-388.

Wu, C. (2013). Disputes on Chinese film box office sales splitting with game theory. New Films, (5): 61-65.

Xia, C. (2002). An elegiac dedicated to the invasion of Hollywood films. Nanfang Weekend, February 28.

Xia, Y. (1960). Representing our times on the screen. People's Daily, September 4.

Xu, M. \& Tian, C. (2013). Cultural deformations and reformulations: a case study of Disney's Mulan in English and Chinese. Critical Arts: A South-North Journal of Cultural and Media Studies, 2: 182-210.

Yin, H. \& Xiao, Z. (2002). Hollywood's globalization strategy and the development of Chinese films. In Zhang, F. (ed.), Globalization and Chinese Films' Fate. Beijing: Beijing Broadcasting Institue Press.

Yu, H., et al. (2012). An analysis of game relations between investment and financing bodies in China's film industry. Shanghai Finance, (3): 100-104.

Zhao, L. (2013). On the "universal strategy": another way of thinking about the relationship between Chinese films and Hollywood. Journal of Northwest University for Nationalities, (3): 158-160. 


\section{Acknowledgement}

Research for this article was funded by the National Planning Office of Philosophy and Social Science, P. R. China (grant no. 12BYY023).

Author Biography
Chuanmao Tian is Professor of English at Yangtze University, Jingzhou, Hubei, P. R. China, with
a PhD degree in Translation and Intercultural Studies. He is the director of the Centre for
Translation Studies, Yangtze University, and an advanced member of the Translators Association of
China (TAC). His area of interest is translation theory and practice. He has published a number of
articles concerning translation and media studies in major scholarly journals at home and abroad,
such as Chinese Translators Journal (2000/2012), Across Languages and Cultures (2010/2014),
Perspectives: Studies in Translatology (2008/2010), Critical Arts: South-North Cultural and Media
Studies (2013), and Continuum: Journal of Media and Cultural Studies (2013).

